\title{
Comparison of proteins expressed by Pseudomonas aeruginosa strains representing initial and chronic isolates from a cystic fibrosis patient: an analysis by 2-D gel electrophoresis and capillary column liquid chromatography- tandem mass spectrometry
}

\author{
Sheri L. Hanna, ${ }^{1}$ Nicholas E. Sherman, ${ }^{1,2}$ Michael T. Kinter ${ }^{1,2,3}$ \\ and Joanna B. Goldberg ${ }^{1}$
}

Author for correspondence: Joanna B. Goldberg. Tel: +1 804243 2774. Fax: +1 8049821071.
e-mail: jbg2b@virginia.edu

1,2 Department of Microbiology ${ }^{1}$ and the W. M. Keck Biomedical Mass Spectrometry Laboratory, Biomolecular Research Facility2, University of Virginia Health Sciences Center, Charlottesville, VA 22908, USA

3 Department of Cell Biology, Lerner Research Institute, Cleveland Clinic Foundation, Cleveland, $\mathrm{OH} 44195$, USA

\begin{abstract}
Isolates of Pseudomonas aeruginosa from chronic lung infections in cystic fibrosis (CF) patients have phenotypes distinct from those initially infecting CF patients, as well as from other clinical or environmental isolates. To gain a better understanding of the differences in these isolates, protein expression was followed using two-dimensional (2-D) gel electrophoresis and protein identification by peptide sequencing using micro-capillary column liquid chromatography-tandem mass spectrometry ( $\mu \mathrm{LC} / \mathrm{MS} / \mathrm{MS})$. The isolates selected for this analysis were from the sputum of a CF patient: strain 383 had a nonmucoid phenotype typical of isolates from the environment, and strain 2192, obtained from the same patient, had a mucoid phenotype typical of isolates from chronic CF lung infections. Strains 383 and 2192 were confirmed to be genetically identical by restriction endonuclease analysis, random amplified polymorphic DNA-PCR, and pulsed-field gel electrophoresis. Conditions of protein extraction were optimized for consistent high-resolution separation of several hundred proteins from these clinical isolates as detected by Coomassie staining of 2-D gels. Fourteen proteins were selected for analysis; this group included those whose expression was common between both strains as well as unique for each strain. The proteins were identified by $\mu L C / M S / M S$ of the peptides produced by an in-gel tryptic digestion and compared to translated data from the Pseudomonas Genome Project; optimization of this technique has allowed for the comparison of proteins expressed by strains 383 and 2192.
\end{abstract}

Keywords: genome analysis, proteomics, peptide sequencing, outer-membrane proteins, genotypic and phenotypic comparison

\section{INTRODUCTION}

Pseudomonas aeruginosa is an opportunistic pathogen that can cause acute infections in compromised patients, including those undergoing chemotherapy, with burns, or with eye injury (Pollack, 2000). P. aeruginosa also

Abbreviations: 2-D, two-dimensional; CF, cystic fibrosis; IPG, immobilized $\mathrm{pH}$ gradient; $\mu \mathrm{LC} / \mathrm{MS} / \mathrm{MS}$, micro-capillary column liquid chromatographytandem mass spectrometry; REA, restriction endonuclease analysis; RAPD, random amplified polymorphic DNA. causes chronic lung infections in patients with cystic fibrosis $(\mathrm{CF})$; this chronic colonization is the major cause of death in these patients (Govan \& Deretic, 1996; Pier, 1998).

The isolates that initially infect the lungs of CF patients have phenotypes typical of those in the environment and from acute infections. These initially infecting strains are highly motile, produce a complete lipopolysaccharide (LPS) with a typical lipid A, and have a nonmucoid phenotype. These isolates also secrete high levels of 
proteases, exotoxins and siderophores (Pollack, 2000). After this initial infection, $P$. aeruginosa undergoes a number of important morphological changes that give isolates from chronic lung infections a distinctive phenotype. Isolates from the chronic lung infections in CF patients are generally non-motile, express a defective LPS, have a penta-acylated lipid A modified with palmitate or aminoarabinose (Ernst et al., 1999), and express lower levels of proteases, exotoxins and siderophores (Pier, 1998). The most obvious alteration in the bacteria is the emergence of isolates with a mucoid appearance. This phenotype is due to the production of large amounts of the mucoid exopolysaccharide alginate. Up to $90 \%$ of CF patients infected with $P$. aeruginosa have mucoid strains chronically colonizing their lungs. The mucoid phenotype in $P$. aeruginosa occurs almost exclusively among lung infections in CF patients and only rarely in other pulmonary infections; thus the isolation of mucoid $P$. aeruginosa is virtually diagnostic of CF (Govan \& Deretic, 1996).

Epidemiological analysis of sequential $P$. aeruginosa strains isolated from the same CF patient indicates that these patients often carry the same strain that has changed its morphological character, presumably to adapt to the environment of the CF lung, rather than acquire new strains with different characteristics (Mahenthiralingam et al., 1996). Thus, isolates from initial and chronic infections in CF can be genetically identical but phenotypically distinct, expressing different proteins, lipids and carbohydrates.

Because of the importance of $P$. aeruginosa as an opportunistic pathogen in both acute and chronic infections, the sequence of the genome of the laboratory strain PAO1 was determined by the Pseudomonas Genome Project (http://www.pseudomonas.com). This resource provides vital information on the identification of proteins encoded by this opportunistic pathogen's DNA and should afford opportunities to determine the functions of these proteins and their role in virulence.

In this study, we have taken advantage of the availability of the completed genome and the techniques of twodimensional (2-D) gel electrophoresis followed by mass spectrometry (MS) to detect variations in protein expression between nonmucoid and mucoid $P$. aeruginosa strains recovered from a CF patient. 2-D gel electrophoresis separates protein mixtures by isoelectric focusing in the first dimension and by SDS-PAGE in the second dimension. The resulting gels provide a highresolution separation of a complex mixture of proteins. In addition, the degree of staining of individual bands represents a quantitative measurement of the relative amounts of the protein, effectively providing a third dimension of information. The amino acid sequence of the selected proteins can be determined by MS and this information can be compared to the Pseudomonas Genome Project database.

Similar proteomic approaches have been used to detect changes in proteins expressed during certain growth conditions. Quadroni et al. (1999) have characterized $P$. aeruginosa proteins induced during sulfate starvation. An 'in house' resource to manage the enormous amount of data that is generated from these sorts of analyses, called The Microbial Proteomic Database, has recently been described (Cordwell et al., 1999). Here we have compared two strains that represent those from initial and chronic lung infections in CF patients to begin to determine how specific proteins may contribute to the observed phenotypic differences between these strains. Changes in protein expression detected through this analysis may reflect changes that are induced by the CF lung environment, those that play a role in survival in the lung environment, or those that contribute to the activities of the organism that are responsible for its pathogenesis. Characterizing these differences will promote further studies on the function and regulation of these particular proteins, their role in virulence, and their potential as novel drug targets or as vaccine candidates.

\section{METHODS}

Bacterial strains, growth and extraction conditions. $P$. aeruginosa 383 was isolated from the sputum of a CF patient at Children's Hospital, Boston, MA, USA, on 16 June 1980 and $P$. aeruginosa 2192 was isolated from the same patient $2 \mathrm{~d}$ later. These strains were kindly provided by Dr Gerald B. Pier, Channing Laboratory, Harvard Medical School, Boston, MA. Both strains were grown in $200 \mathrm{ml} \mathrm{L}$ broth at $37^{\circ} \mathrm{C}$ in a shaker for $26 \mathrm{~h}$. Whole cells were diluted with one part saline and centrifuged at $9000 \mathrm{~g}$ for $20 \mathrm{~min}$. Pellets were washed in the same volume of saline and centrifuged as before. The final pellet was resuspended in $20 \mathrm{ml}$ HEPES $(0 \cdot 1 \mathrm{M}, \mathrm{pH} 7 \cdot 4)$, and a small aliquot of both RNase $\left(100 \mu \mathrm{g} \mathrm{ml}^{-1}\right)$ and DNase I $(100 \mu \mathrm{g}$ $\mathrm{ml}^{-1}$ ) was added to the solution. The cells were lysed via French press at 16000 p.s.i. (110 MPa) twice. One millilitre of $10 \mathrm{mM} \mathrm{MgCl}{ }_{2}$ was added to each sample to help clear any residual nucleic acid, and extracts were clarified by low-speed centrifugation $(5000 \mathrm{~g})$ for $5 \mathrm{~min}$. The bacterial extract was divided into aliquots and stored at $-80{ }^{\circ} \mathrm{C}$. Protein concentrations were determined using the standard protocol in the BCA Protein Assay Reagent Kit (Pierce Chemical Co.).

DNA analysis. Genomic DNA was isolated using a Puregene DNA Isolation Kit (Gentra Systems) following the protocol for Gram-negative bacteria. Restriction endonuclease digestions were performed according to the manufacturer's instructions (Boehringer Mannheim Biochemicals).

Random amplified polymorphic DNA (RAPD)-PCR analysis was performed as described by Mahenthiralingam et al. (1996). Genomic DNA from $P$. aeruginosa strain PAO1 (Kropinski et al., 1979) was used as a control in this analysis. Briefly, PCR was performed using Easy Start Micro 20 (Molecular Bio-Products) including 2.0 $\mu$ l of 1:20 dilution of purified genomic DNA, 40 pmol primer 272 [5'-AGCGGGCCAA-3' (Mahenthiralingam et al., 1996), purchased from Ransom Hill Bioscience], $0.5 \mu \mathrm{l}$ Taq polymerase $\left(5\right.$ units $\mu^{-1}$ ) and $7 \cdot 1 \mu \mathrm{l}$ distilled $\mathrm{H}_{2} \mathrm{O}$ for a total reaction volume of $10 \mu \mathrm{l}$. PCR was performed as follows: four cycles of $5 \mathrm{~min}$ at $94^{\circ} \mathrm{C}$, $5 \mathrm{~min}$ at $36^{\circ} \mathrm{C}$ and $5 \mathrm{~min}$ at $72^{\circ} \mathrm{C} ; 30$ cycles of $1 \mathrm{~min}$ at $94^{\circ} \mathrm{C}$, $1 \mathrm{~min}$ at $36^{\circ} \mathrm{C}$ and $1 \mathrm{~min}$ at $72{ }^{\circ} \mathrm{C}$; final $10 \mathrm{~min}$ at $72{ }^{\circ} \mathrm{C}$, and hold at $4{ }^{\circ} \mathrm{C}$. DNA products were visualized by agarose gel electrophoresis as previously described (Dean et al., 1999).

Samples for PFGE were prepared as described by Vandamme et al. (2000). These samples were treated with the restriction 
enzyme SpeI and separated on a CHEF-DR II apparatus (Bio$\mathrm{Rad}$ ) using the following cycle: block $1,6 \mathrm{~V}, 1-40 \mathrm{~s}$ for 10 $\mathrm{h}$; and block 2, $6 \mathrm{~V}, 30-90 \mathrm{~s}$ for $14 \mathrm{~h}$.

Cell fractionation. Bacterial outer-membrane extracts were purified using the same bacterial growth and whole-cell lysis protocol described above. The lysate was centrifuged at $40000 \mathrm{~g}$ for $1 \mathrm{~h}$. An outer-membrane extract was obtained by adding $10 \%$ Sarkosyl to a final concentration of $2 \%$ to the original extract, which was then allowed to sit on ice for $30 \mathrm{~min}$ prior to the final centrifugation. This addition results in a pellet fraction that contains only outer-membrane proteins and a supernatant that contains inner-membrane and cytoplasmic proteins (Sprott et al., 1994). Outer-membrane proteins were separated in one dimension on $12.5 \%$ SDSPAGE $(16 \mathrm{~cm} \times 16 \mathrm{~cm})$ and visualized by Coomassie staining.

Phenol extraction prior to 2-D gel electrophoresis. A phenol extraction was performed on bacterial extracts prior to 2-D gel electrophoresis using a protocol previously described by Hancock \& Nikaido (1978). Briefly, 1-2 ml aliquots of the extracts were thawed and transferred to $15 \mathrm{ml}$ polypropylene tubes. One millilitre of phenol was added, and the sample was vortexed and heated at $70{ }^{\circ} \mathrm{C}$ for $10 \mathrm{~min}$ in a fume hood. The sample was cooled on ice and phases separated by centrifugation at $5000 \mathrm{~g}$ for $10 \mathrm{~min}$. The top aqueous phase was discarded and $1 \mathrm{ml}$ distilled $\mathrm{H}_{2} \mathrm{O}$ was added. The sample was vortexed and heated at $70{ }^{\circ} \mathrm{C}$ for $10 \mathrm{~min}$. The sample was cooled on ice, the phases separated by centrifugation as before, and the top aqueous phase discarded. Proteins were precipitated by addition of $2 \mathrm{ml}$ cold acetone. The sample was pelleted by centrifugation and the supernatant was poured off. One millilitre of acetone was added, the pellet was disrupted by vigorous vortexing, and the precipitated proteins were pelleted by a final centrifugation. The supernatant was poured off and the pellet air-dried in a hood.

2-D gel electrophoresis. The precipitated protein from the phenol extraction was solubilized in $7 \mathrm{M}$ urea, $2 \mathrm{M}$ thiourea, $4 \%$ CHAPS, $50 \mathrm{mM}$ DTT at a concentration of $10 \mathrm{mg} \mathrm{ml}^{-1}$. This stock sample was frozen at $-80^{\circ} \mathrm{C}$ until analysis. For the 2-D analysis, the stock sample was thawed and $300 \mu \mathrm{l}$ of the sample was mixed with $100 \mu \mathrm{l}$ of a buffer containing $7 \mathrm{M}$ urea, $2 \mathrm{M}$ thiourea, 4\% CHAPS, 5\% carrier ampholytes, 5\% Triton X-100, $50 \mathrm{mM}$ DTT to give $3 \mathrm{mg}$ cell protein per $400 \mu \mathrm{l}$ sample. 2-D electrophoresis was performed using immobilized $\mathrm{pH}$ gradient (IPG) strips. The IPG strips, $18 \mathrm{~cm}$ long and covering $\mathrm{pH} 3-10$, were rehydrated with the entire protein sample overnight at room temperature under mineral oil. After rehydration, isoelectric focusing in the IPG strip was carried out for a total of $89 \cdot 7 \mathrm{kVh}$ at $20{ }^{\circ} \mathrm{C}$ under mineral oil. The focused strip was first reduced in a $60 \mathrm{mM}$ Tris buffer containing $6 \mathrm{M}$ urea, $30 \%$, v/v, glycerol, $1 \%$ SDS and $15 \mathrm{mM}$ DTT for $15 \mathrm{~min}$ at room temperature, and then alkylated in the same Tris buffer containing $150 \mathrm{mM}$ iodoacetamide. The strip was then run into a $22 \mathrm{~cm} \times 22 \mathrm{~cm}, 10 \%$ SDS-PAGE gel for the molecular mass dimension of the electrophoresis. Broad-range molecular mass markers were purchased from Genomic Solutions and were run on parallel gels under identical conditions. Proteins bands were detected by Coomassie staining.

Mass spectrometric sequencing. The selected protein spots were cored from the gels and placed in a siliconized microcentrifuge tube that had been rinsed with ethanol, water and ethanol. The gel pieces were washed and destained in $0.5 \mathrm{ml}$ $50 \%$ methanol $/ 5 \%$ acetic acid overnight at room temperature before dehydration in $200 \mu \mathrm{l}$ acetonitrile and complete drying in a vacuum centrifuge. The proteins were reduced by addition of $50 \mu \mathrm{l} 10 \mathrm{mM}$ DTT and alkylated by addition of $50 \mu \mathrm{l}$
$100 \mathrm{mM}$ iodoacetamide (both $30 \mathrm{~min}$ at room temperature). To exchange the buffer, the gel pieces were dehydrated in $200 \mu \mathrm{l}$ acetonitrile, hydrated in $200 \mu \mathrm{l} 100 \mathrm{mM}$ ammonium bicarbonate and dehydrated again with $200 \mu$ l acetonitrile. The dehydrated gel pieces were then dried completely in a

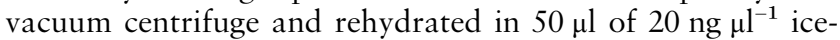
cold, sequencing-grade modified porcine trypsin (Promega) for 5 min on ice. Any excess trypsin solution was removed and the digestion carried out overnight at $37^{\circ} \mathrm{C}$. The peptides produced in the digest were collected by successive extractions with $50 \mu \mathrm{l} 50 \mathrm{mM}$ ammonium bicarbonate and $50 \mu \mathrm{l} 50 \%$ acetonitrile $/ 5 \%$ formic acid $(2 \times)$, combining the extracts in a siliconized $0.6 \mathrm{ml}$ microcentrifuge tube that had been previously rinsed with ethanol, water and ethanol. The total extract was concentrated in a vacuum centrifuge to $20 \mu \mathrm{l}$ for analysis.

The $\mu$ LC-MS system consisted of a Finnigan LCQ (ThermoQuest) ion-trap mass spectrometer with a Protana nanospray ion source interfaced to a self-packed $8 \mathrm{~cm} \times 75 \mu \mathrm{m}$ i.d. Phenomenex Jupiter $10 \mu \mathrm{m}$ C18 reverse-phase capillary column; $0.5 \mu \mathrm{l}(2.5 \%)$ volumes of peptide extract were injected and the peptides eluted from the column with an acetonitrile $/ 0 \cdot 1 \mathrm{M}$ acetic acid gradient (2-85\% acetonitrile in $30 \mathrm{~min}$ ) at a flow rate of $0 \cdot 25 \mu \mathrm{l} \mathrm{min}{ }^{-1}$. The microspray ion source was operated at $2 \cdot 8 \mathrm{kV}$. The digest was analysed using a full datadependent acquisition routine in which a full-scan mass spectrum (MS) to determine peptide molecular masses was acquired in one scan and product-ion (MS/MS) spectra to determine amino acid sequence were acquired in the four scans before the cycle repeats. This mode of analysis produces approximately $500 \mathrm{MS} / \mathrm{MS}$ spectra of peptides ranging in abundance over several orders of magnitude. Not all MS/MS spectra are derived from peptides.

Database searches for protein identification. The resulting MS/MS spectra were automatically batch-analysed for each spot using Sequest against the $P$. aeruginosa genome sequence using the Pseudomonas Genome Project as the database. ORFs found were subsequently searched using BLAST (National Center for Biotechnology Information) against their non-redundant database.

\section{RESULTS}

\section{P. aeruginosa strains 383 and 2192 are genetically identical}

To begin to define differences between proteins expressed by strains of $P$. aeruginosa from initial and chronic infections, we chose to study strains 383 and 2192, which were isolated from the sputum of the same CF patient $2 \mathrm{~d}$ apart. The phenotype of these strains is distinct : 383 is nonmucoid and 2192 is mucoid. Since CF patients can sometimes be colonized with different strains and because different strains can predominate in the lungs of patients with CF (Kersulyte et al., 1995; Mahenthiralingam et al., 1996), three separate genotyping methods were used to determine whether these strains were related to one another. This was critical to establish since we are interested in defining differential protein expression in genetically related strains rather than analysing proteins that vary due to individual strain differences.

The first technique, restriction endonuclease analysis (REA) of $P$. aeruginosa DNA, relies on the resolution of restriction fragments by agarose gel electrophoresis after 
(a)
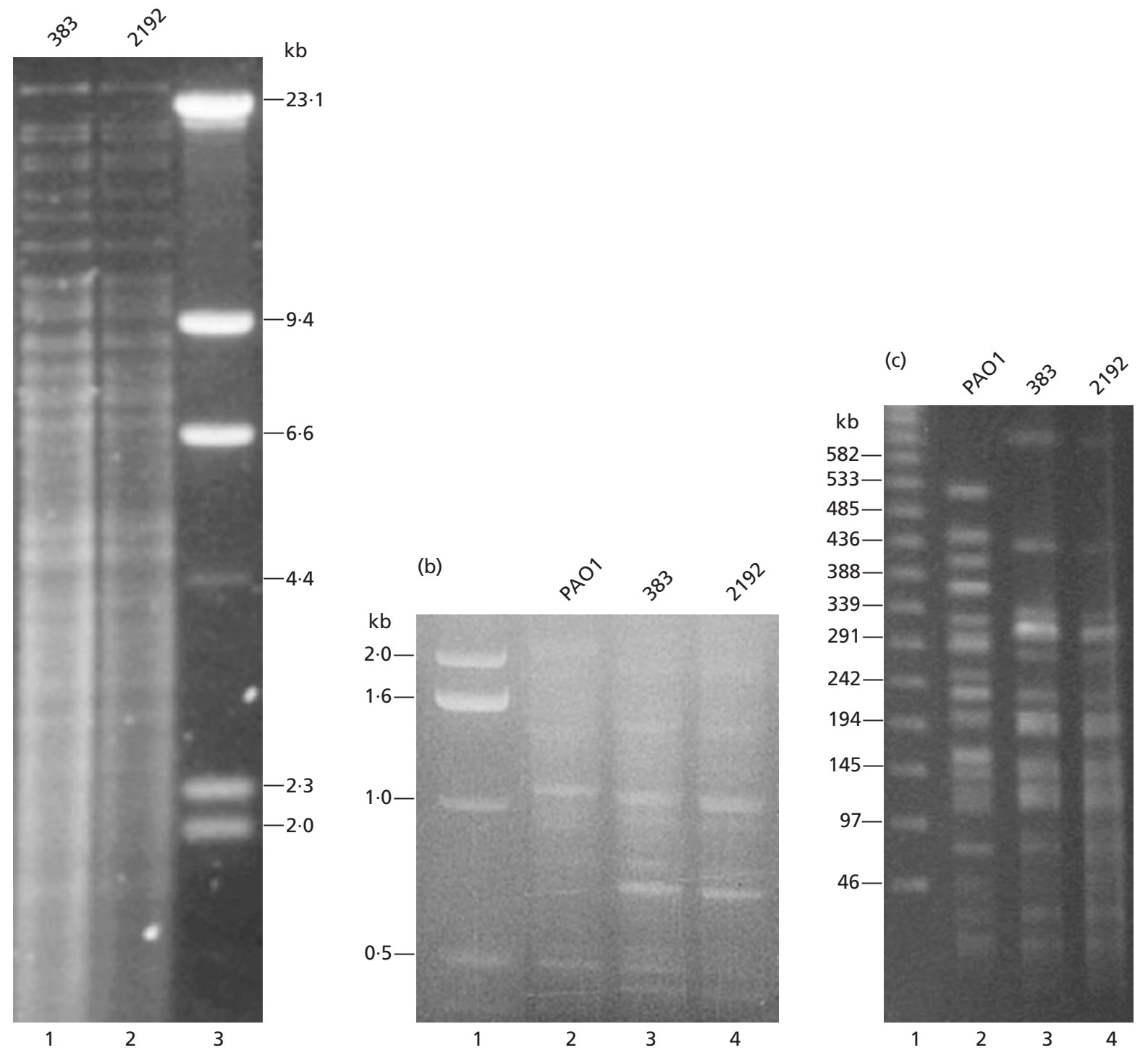

Fig. 1. (a) REA analysis of genomic DNA from $P$. aeruginosa 383 (lane 1) and 2192 (lane 2). DNA samples were digested with Sall and subjected to $0.5 \%$ agarose gel electrophoresis. Lambda Hindlll size markers were run in lane 3. (b) RAPD analysis of genomic DNA from $P$. aeruginosa strains with primer 272. The fingerprint patterns of 383 (lane 3 ) and 2192 (lane 4) appear identical and distinct from that of PAO1 (lane 2). DNA size marker was run in lane 1. (c) PFGE analysis of P. aeruginosa PAO1 (lane 2), 383 (lane 3), and 2192 (lane 4). Samples were digested with Spel and separated on a CHEFDR II apparatus. The DNA size marker (lane 1) was a lambda ladder (Bio-Rad).

digestion with specific restriction enzymes. The comparisons of sizes of fragments visualized in the molecular mass range $8 \cdot 3-48 \mathrm{~kb}$ after digestion with SalI allows similar $P$. aeruginosa strains to be grouped together (Maher et al., 1993). Fig. 1(a) shows the results of REA using genomic DNA from strains 383 and 2192 digested with SalI; the similarities of the two fingerprints are obvious and easy to visualize.

The second method used for typing these strains was RAPD-PCR analysis. This rapid method was developed to monitor the similarity of sequential $P$. aeruginosa strains isolated from CF patients (Mahenthiralingam et al., 1996). RAPD-PCR was performed on DNA isolated from strains 383 and 2192; DNA from the laboratory strain PAO1 was used for comparison (Fig. 1b). The banding patterns of PCR products from strains 383 and 2192 were similar to one another, while the pattern of the products from PAO1 was different.

The third technique used for strain discrimination was PFGE (Vandamme et al., 2000). This technique, sometimes considered the 'gold standard' for genetic mapping and typing, relies on the digestion of DNA with a restriction enzyme that cuts infrequently. In the case of $P$. aeruginosa, the enzyme SpeI has been used for this type of analysis (Römling et al., 1992; Holloway et al., 1994). Large DNA fragments are then separated on a 


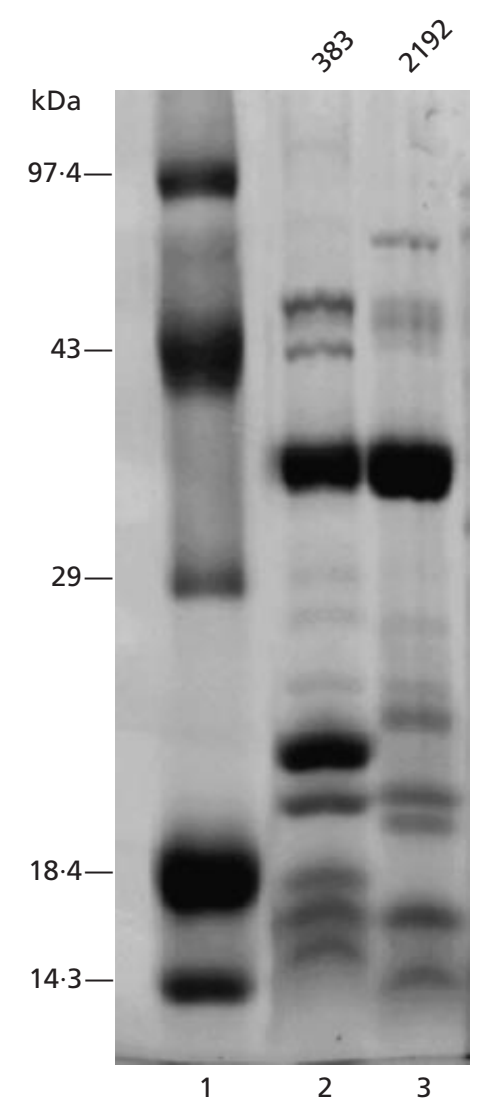

Fig. 2. Outer-membrane protein profiles of $P$. aeruginosa strains 383 and 2192 separated by one-dimensional 12.5\% SDSPAGE and stained with Coomassie blue. Protein molecular mass standard was run in lane 1. Lanes 2 and 3, outer-membrane proteins from 383 and 2192, respectively.

pulsed-field gel apparatus. Strains 383 and 2192 appeared identical by this analysis, while PAO1 appeared distinctly different (Fig. 1c).

The results of all of these genotypic studies indicated that strains 383 and 2192 are isogenic.

\section{One-dimensional gel electrophoresis of outer-membrane proteins}

Alterations in outer-membrane proteins have been noted between mucoid and nonmucoid strains of $P$. aeruginosa (Grabert et al., 1990; Kelly et al., 1990). Due to their accessibility on the outer surface of the bacteria, outer-membrane proteins have been suggested as useful targets for vaccine development and as carriers for foreign epitopes; therefore understanding the variability in their expression in various strain backgrounds is of critical importance (Hancock et al., 1990). To determine whether there were differences between strains 383 and 2192, outer-membrane proteins were extracted. Coomassie-stained one-dimensional gels of outer-membrane proteins identified distinctive band differences between the nonmucoid strain 383 and mucoid strain 2192 (Fig. 2). Unique protein bands were found in the outer- membrane extract of nonmucoid strain 383 at approximately 57, 45, 22 and $18 \mathrm{kDa}$ (Fig. 2). Conversely, unique bands were noted in the outer-membrane extracts of mucoid strain 2192 at approximately 68, 54, 25, 20 and $14 \mathrm{kDa}$ (Fig. 2).

\section{2-D gel electrophoresis}

To further characterize protein expression differences between the nonmucoid strain 383 and the mucoid strain 2192, 2-D gel electrophoresis of whole-cell extracts was performed. In preliminary experiments, using techniques described for Chlamydia trachomatis (Bini et al., 1996), the cell lysates proved to be very viscous and no more than $200 \mu \mathrm{g}$ protein could be loaded in each gel. The viscosity of the solubilized homogenates prevented accurate loading and proper electrophoresis of the IPG strip, although interestingly, this viscosity problem was not observed with the laboratory strain, PAO1. Although individual protein points were not well focused, even these initial 2-D gels showed pattern differences between strains 383 and 2192 (data not shown). Using one-dimensional SDS-PAGE, Hancock \& Nikaido (1978) found that phenol extraction resulted in tighter bands and minimal change in protein migration rates. We therefore performed this phenol extraction technique prior to 2-D gel electrophoresis. In addition, in these subsequent experiments, DNase I and RNase were added to remove any extraneous nucleic acid from the cell lysate. The steps associated with this extraction and subsequent precipitation produced protein pellets that were easily solubilized under conditions that were optimal for the isoelectric focusing. The application of these two processes resulted in 2-D gels with clearly focused protein patterns and the ability to load higher volumes of protein. Fig. 3 shows Coomassie-stained gels of proteins extracted from strains 383 and 2192 in which the isoelectric dimension covers the isoelectric points between 3 and 10. The IPG system used in these gels is non-linear, but provides a reliable survey of the proteins present in each gel.

\section{Selection of proteins to be analysed}

Fourteen protein spots were selected from the 383 and 2192 gels for sequencing by MS/MS. Spots 1-10 were cored from the 2-D gel containing proteins isolated from the nonmucoid strain 383 (Fig. 3a) and spots 11-14 were obtained from the 2-D gel of proteins from the mucoid strain 2192 (Fig. 3b). Spots 1 and 2 were selected because they appeared invariant between the gels (common). Spots 3, 4 and 5 were chosen because they appeared only in the 383 gel (unique). Additionally, 6, 7, 8, 9 and 10 were selected because they appeared in both gels, but were overexpressed in 383 (overexpressed). Spots 11, 13 and 14 were chosen because they appeared only in the 2192 gel (unique) and spot 12 was chosen because it was overexpressed in 2192 (overexpressed). The corresponding spots from each gel for most of the overexpressed and common proteins were cored and analysed. 
(a)

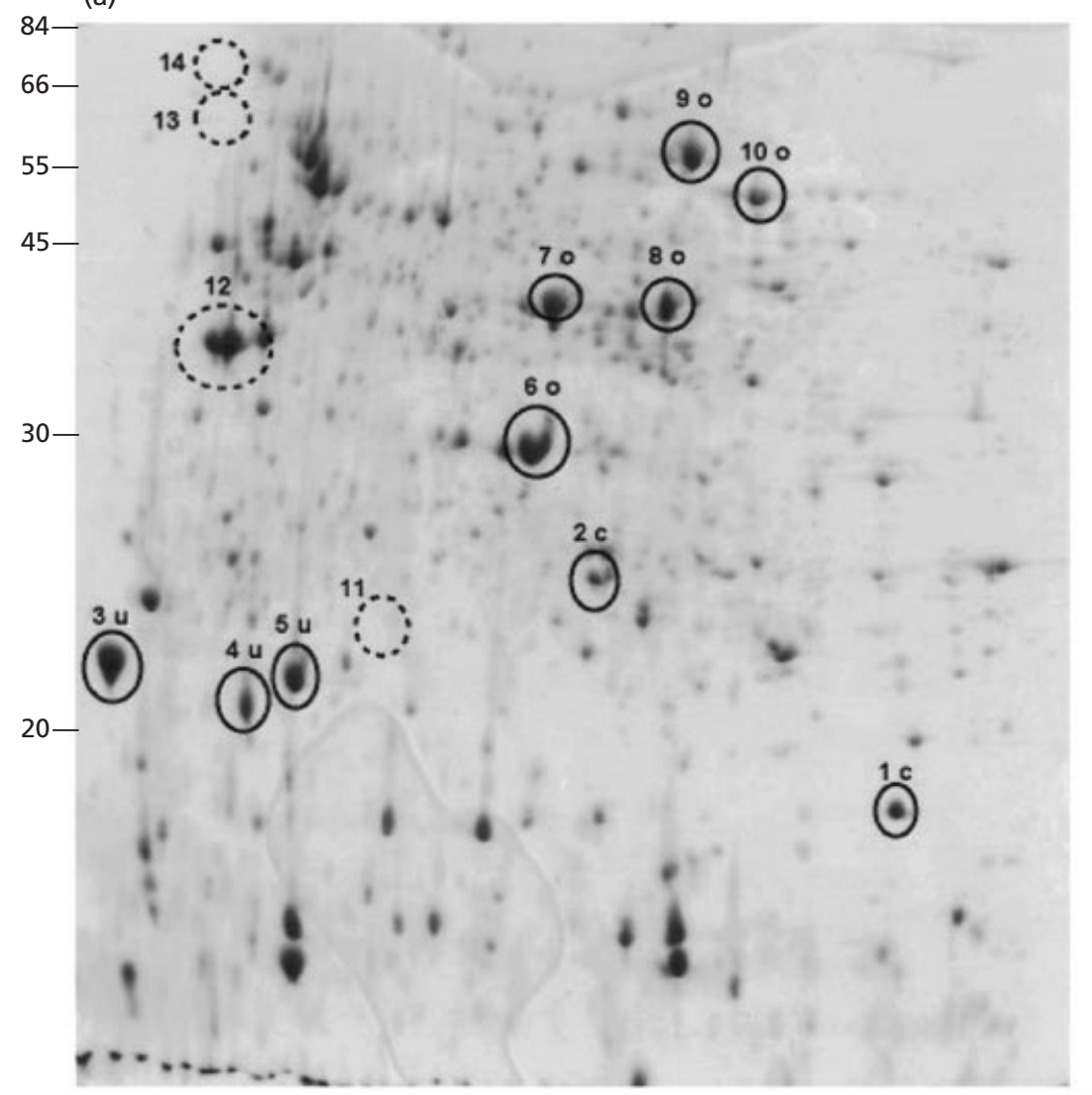

(b)

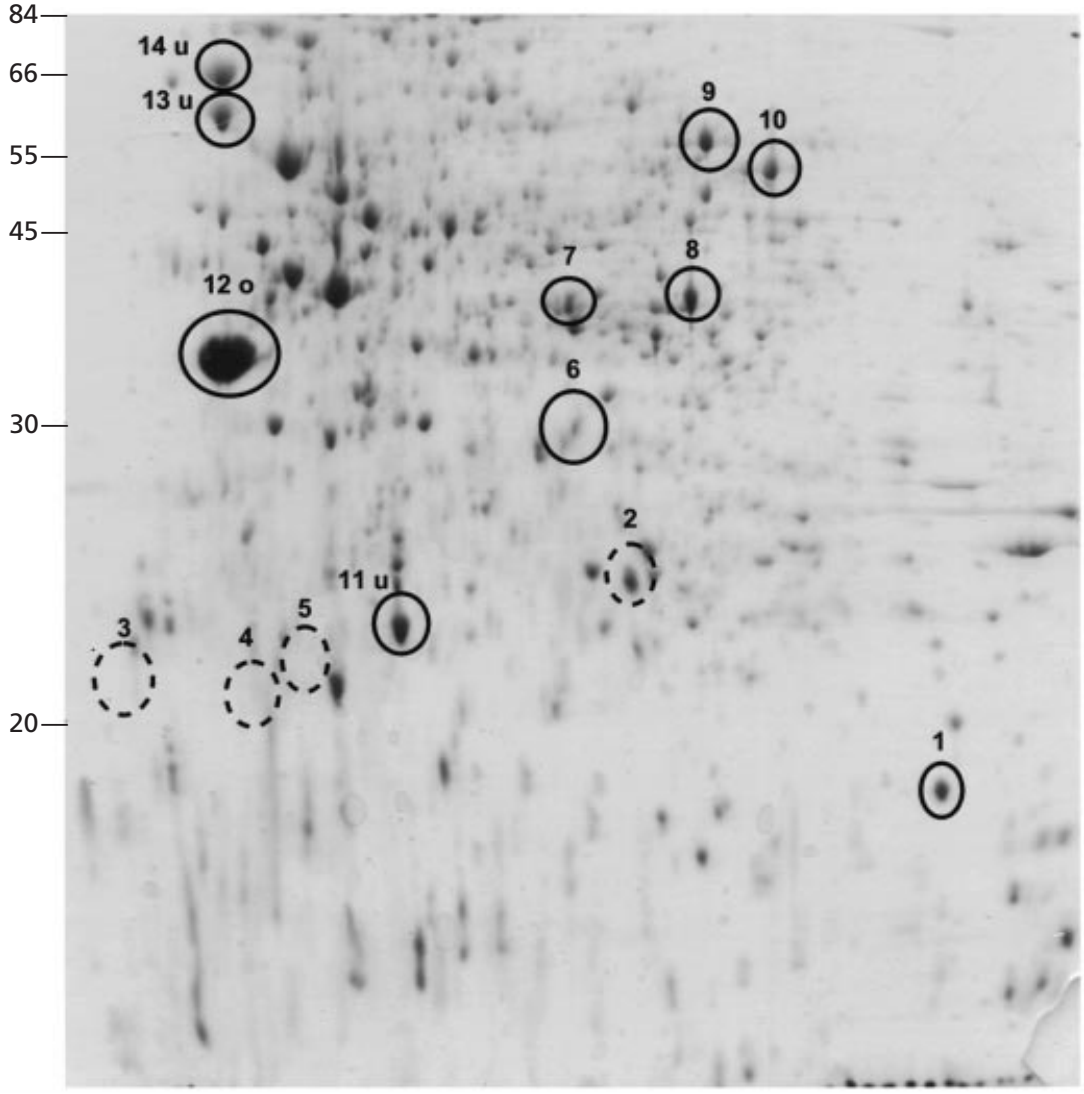

Fig. 3. 2-D gel analysis of proteins of $P$. aeruginosa 383 (panel a) and 2192 (panel b). Three milligrams of protein was focused in a pH gradient of 3 to 10. After isoelectric focusing, the sample was run on $10 \%$ SDS-PAGE and subsequently stained with Coomassie blue. The proteins were selected as common (c), unique (u), or overexpressed (o) between the gels. Protein spots that were analysed are indicated with solid circles. Protein spots that were unique to a particular gel and two not recovered for technical reasons are indicated with dashed circles. In all overexpressed or common spots analysed, identical identifications were obtained. Molecular masses were determined on a parallel gel; the sizes in kDa are indicated to the left of the gels. The $\mathrm{pH}$ gradient is non-linear from 3 (left) to 10 (right). 


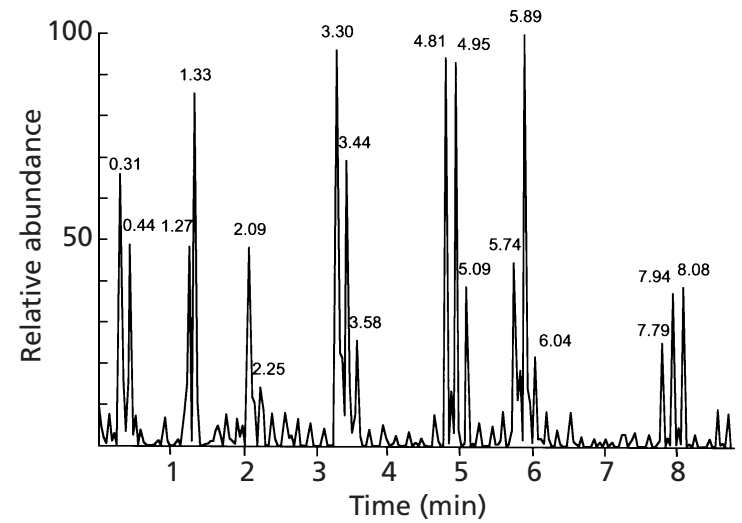

Fig. 4. Reconstructed ion chromatogram from the $\mu \mathrm{LC}-\mathrm{MS}$ analysis of spot 6 . The chromatogram is reconstructed by plotting the abundance of the most abundant ion (the base peak) in each spectrum. The sharp appearance of the chromatographic peaks is due to the changing acquisition mode used in the data-dependent data acquisition.

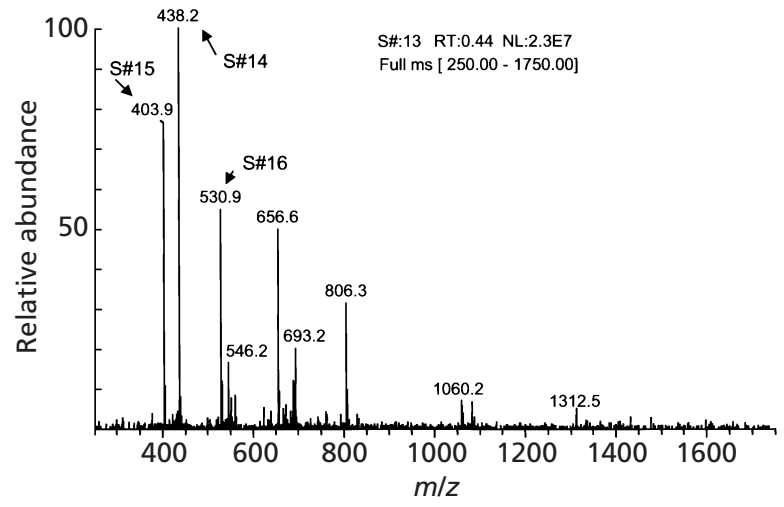

Fig. 5. A mass spectrum acquired during the $\mu \mathrm{LC}-\mathrm{MS}$ analysis of spot 6 (electrospray mass spectrum of the peptide eluting at $0.44 \mathrm{~min}$ in the 13th scan in the reconstructed chromatogram, shown in Fig. 4). Singly, doubly and triply charged ions from at least three peptides can be seen in this spectrum. The datadependent data acquisition automatically programs the instrument to acquire product-ion spectra for the four most abundant ions, which are acquired in scans 14, 15, 16 and 17.

\section{Protein identification by MS/MS}

As an example of the analysis that was performed on each of these proteins, data obtained for spot number 6 (PA6) are shown in Figs 4, 5 and 6. The analysis was carried out with an ion-trap detector in data-dependent acquisition mode. In this mode, the instrument acquires a mass spectrum (MS) and automatically analyses that spectrum to determine the four most abundant ions. The instrument's acquisition is then instantly reprogrammed to acquire product-ion spectra (MS/MS) for each of these ions.

Fig. 4 shows part of a reconstructed ion chromatogram derived from the analysis of the tryptic digest of spot no. 6 (PA6). From this approximately 9 min acquisition

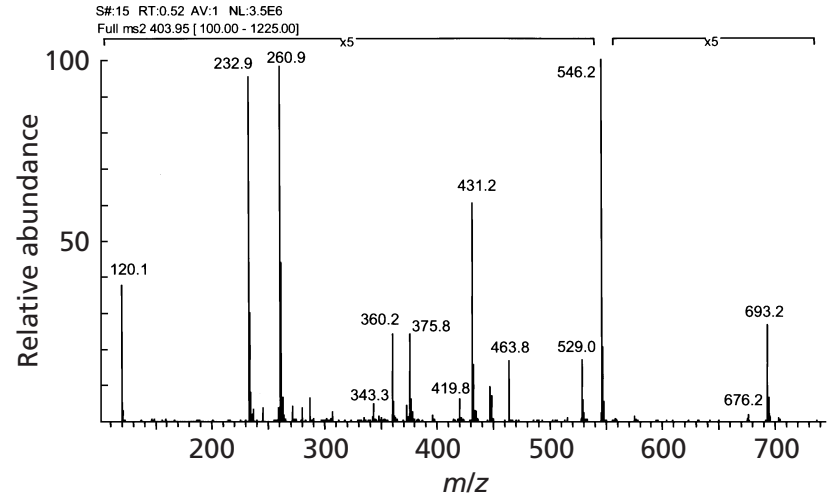

Fig. 6. Product-ion spectrum of a peptide with a measured molecular mass of 806.3 $\mathrm{Da}\left(\mathrm{M}+\mathrm{H}^{+}\right)$. The product-ion spectrum acquired in scan 15 fragmented the doubly charged ion at $\mathrm{m} / \mathrm{z}$ 403.9. This spectrum contains sufficient information to deduce the entire sequence of the peptide as XFDAQGR, where $X$ denotes either $L$ or $I$, which cannot be distinguished by lowenergy collisional activation. Database searches of this spectrum, without any interpretation, using the search program Sequest identified this peptide in the sequence of the contiguous genome from the Pseudomonas Genome Project.

period about $275 \mathrm{MS} / \mathrm{MS}$ spectra were obtained. The apparent chromatographic peaks seen in the figure are not true chromatographic peaks but rather maxima produced when the instrument switches from MS mode, which generally produces a higher ion current, to MS/MS mode.

A mass spectrum (MS) from an early portion of this analysis is shown in Fig. 5. This spectrum indicates the elution of at least three prominent peptides at this time point. The subsequent four spectra acquired, as noted in the spectrum, are product-ion spectra (MS/MS) of the four most abundant ions in this mass spectrum. One of these product spectra is shown in Fig. 6, which was used directly to search the Pseudomonas Genome Project database and identify the protein sequence shown in Fig. 7 (PA6).

Analysis of all the data acquired for PA6 identified the tryptic peptides shown in Fig. 7 (underlined). The protein that was identified has 389 amino acids, with a calculated molecular mass of $41.9 \mathrm{kDa}$ and a calculated pI of $6 \cdot 65$. The peptides detected cover 115 of the amino acid residues or $30 \%$ of the sequence, providing a strong identification. A BLAST search revealed a match to a chitin-binding protein, $\mathrm{ChpD}$.

Similar protein sequencing and analysis provided identifications for all 14 spots cored from the gels to ORFs in the Pseudomonas Genome Project database (version 15 December 1999). In all cases, the peptides in the digest (at greater than $10 \%$ relative abundance in the MS spectra) matched a unique ORF from the database. These are shown in Fig. 7 and summarized in Table 1. The identity of all overexpressed and common proteins was determined to be identical in both gels, except PA2 and PA12, which were not recovered for technical reasons. PA2 and PA12 do match the same location on 


\section{PA1}

MKALKTLFIATALLGSAAGVQAADNFVGLTWGETSNNIOKSKSLNRNLNSPNL DKVIDNTGTWGIRAGQQFEQGRYYATYENISDTSSGNKLRQONLLGSYDAFLP IGDNNTKLFGGATLGLVKLEQDGKGFKDSDVGYAAGLOAGILOELSKNAS IE GGYRYLRTNASTEMTPHGGNKLGSLDLHSSSOFYLGANYKF

\section{PA3}

MKLKNTLGVVIGSLVAASAMNAFAQGQNSVEIEAFGKRYFTDSVRNMKNADLY GGSIGYFLTDDVELALSYGEYHDVRGTYETGNKKVHGNLTSLDAI YHFGTPGV GLRPYVSAGLAHQNITNINSDSQGRQQMTMANI GAGLKYYFTENFFAKASLDG QYGLEKRDNGHQGEWMAGLGVGFNFGGSKAAPAPEPVADVCSDSDNDGVCDNV DKCPDTPANVTVDANGCPAVAEVVRVQLDVKFDFDKSKVKENSYADIKNZADF MKOYPSTSTTVEGHTDSVGTDAYNOKLSERRANAVRDVLVNEYGVEGGRVNAV GYGESRPVADNATAEGRAINRRVEAEVEAEAK

\section{PA5}

MAFELPPLPYEKNALEPHISAETLEYHHDKHHNTYVVNLNNLIPGTEFEGKSL EEIVKSSSGGI FNNAAQVWNHTFYWNCLSPNGGGQPTGALADAINAAFGSFDK EKEEFTKTSVGTFGSGWGWLVKKADGSLALASTIGAGNPLTSGDTPLLTCDVW EHAYY IDYRNLRPKYVEAFWNLVNWDFVAKNFAA

\section{PA7}

MKHYSATLALLPLTLALFLPQAAHAHGSMETPPSRVYGCELEGPENPKSAACK AAVAAGGTQALYDWNGWNQGNANGNHQAVVPDGQLCGAGKALFKGLNLARSDW PSTAIAPDASGNFQFVYKASAPHATRYFDFYITKDGYNPEKPLAWSDLEPAPF CSITSVKLENGTYRMNCPLPOGKTGKHVI YNVWORSDSPEAFYACIDVSFSGA VANPWQALGNLRAQQDLPAGATVTLRLFDAQGRDAQRHSLTLAOGANGAKOWP LALAQKVNQDSTLVNIGVLDAYGAVSPVASSQDNQVYVRQAGYREOVDIELPV EGGGEQPGGDGKVDFDYPQGLQOYDAGTVVRGADGKRYQCKPYPNSGWCKGWD LYYAPGKGMAWQDAWTLL

\section{PA9}

MEEKTRLTTAAGAPVVDNQNVQTAGPRGPMLLQDVWFLEKLAHFDREVIPERR MHAKGSAAYGTFTVTHDITPYTRAKIFSQVGKKTDMFLRFSTVAGERGAADAE RDIRGFSMRFYTEQGNWDLVGNNT PVFYLRDPLKFPDLNHVVKRDPRTNLRNA TFKWDFFSHLPESLHQLTIDFSDRGLPKSYRHIHGFGSHTFSFINANNERFWV KFHFKTQQGIENLTNAEAAEVIAQDRESSQRDLYESIEKGDFPRWKMYVQIMP EKEAATYRYNPFDLTKVWPHGDYPLI EVGFFELNRNPDNYFAEVEQAAFTPAN VVPGIGFSPDKMLQGRLFSYGDAHRYRLGVNHHOIPVNAARCPHQVYHRDGGM RVDGNNAHQRVTYEPNSFNQWQEQPDFSEP PLSLEGAADHWNHRVDDDYYSQP AALFHLFTDEQKQRLFANIAEDIRDVPEQIQRROIGLFLKVDPAYGKGVADAL GLKLD

PA11

MSVLVGKKAPDFNVAAVLGNGEIVESFTLSEAIKGKYGLVFFYPLDFTFVCPS ELIALDHRIPEFOARNVEVIGVSIDSHFTHNAWRNTPVDKGGIGAVKYTLAAD TKHE I AKAYDVESDGGVAERGAFLIDKEGVVRSOIVNDLPIGRNMDELIRLVD ALQFHEEHGEVCPANWKKGDKGMTAS PEGVAKYLAENASKL

PA13

MSESFAELFEESLKSLDMQPGAI ITGIVVDIDGDWVTVHAGLKSEGVIPVEQF YNEOGELTIKVGDEVHVALDAVEDGFGETKLSREKAKRAESWIVLEAAFAADE VVKGVINGKVKGGETVDVNGIRAFLPGSLVDVRPVRDTTHLEGKELEFKVIKL DQKRNNVVSRRSVLEAENSAEREALIESLQEGOOVKGIVKNLTDYGAFVDLG GVDGLLH ITDMAWKRIKHPSE IVNVGDEIDVKVLKFDRERNRVSLGLKQLGED PWVAIKARYPEGTRVMARVTNLTDYGCFAELEEGVEGLVHVSEMDWTNKNIHP SKVVQVGDEVEVOVLDIDEERRRISLGI KQCKSNPWEDESSQFNKGDRISGTI KSITDFGIFIGLDGGIDGLVHLSDISWNEVGEEAVRRFKKGDELETVILSVDP ERERISLGIKQLEDDPFSNYASLHEKGS IVRGTVKEVDAKGAVISLGDDIEGI LKASE I SRDRVEDARNVLKEGEEVEAKI I I I DRKSRVI SLSVKSKDVDDEKDA MKELRKOEVESAGPTTIGDLIRAQMENQG

\section{RA2}

MVDFILNAOVRSDLGKGASRRLRRNAGLVPAVYYGGDKEPOSVTLELREIAKL LENEAAFSHVIALNVGGAKETVLIKALQRHPAKGFVMHADFLRVVADHKLTAH VPLHFINEEVAVGVKOAGGEI SHT I SEVEVSCLPKDLPEE IEVDMAKVELGOI VHLSDLKAPKGVELVOLAHGNDLAVANIHASRVVKEEGSEEGAAE

\section{PA4}

MSVLVGKKAPDFNVAAVLGNGEIVESFTLSEAIKGKYGLVFFYPLDFT FVCPS ELIALDHRIPEFOARNVEVIGVSIDSHFTHNAWRNT PVDKGGIGAVKYTLAAD TKHEIAKAYDVESDGGVAFRGAFL IDKEGVVRSOIVNDLPLGRNMDELLRLVD ALQFHEEHGEVCPANWKKGDKGMTASPEGVAKYLAENASKL

\section{PA6}

MKHYSATLALLPLTLALFLPQAAHAHGSMETPPSRVYGCFLEGPENPKSAACK AAVAAGGTQALYDWNGVNQGNANGNHQAVVPDGQLCGAGKALFKGLNLARSDW PSTAIAPDASGNEOFVYKASAPHATRYFDFYITKDGYNPEKPLAWSDLEPAPF CSITSVKLENGTYRMNCPLPOGKTGKHVIYNVWORSDSPEAFYACIDVSFSGA VANPWQALGNLRACODLPAGATVTLRLFDAOGRDAQRHSLTLAOGANGAKOWP LALAQKVNQDSTLVNIGVLDAYGAVSPVASSQDNQVYVRQAGYREOVDIELPV EGGGEOPGGDGKVDFDYPQGLQQYDAGTVVRGADGKRYQCKPYPNSGWCKGWD LYYAPGKGMAWQDAWTLL

PAB

AFNMHNRNLLSLMHHSTRELRYLLDLSRDLKRAKYTGTEQQHLKRKNIALIFE KTSTRT RCAFEVAAYDOGANVTYIDPNSSOIGHKESMKDTARVLGRMYDAIEY RGFKOEIVEELAKEAGVPVENGLTDEYHPTOMLADVLTMREHSDKPLHDISYA YLGDARNNMGNSLLLIGAKLGMDVRIAAPKALWPHDEFVAQCKKFAEESGAKL TLTEDPKEAVKGVDFVHTDVWVSMGEPVEAWGERI KELLPYOVNMEIMKATGN PRAKFMHCLPAFHNSETKVGKQIAEQYPNLANGIEVTEDVFESPYNIAFEQAE NRMHTIKAILVSTLADI

PA10

SQKEDVVVIGAGPGGYVAAIRAAQLGLKTACIEKYIGKEGKVALGGTCLNVGC IPSKALLDSSYKYHEAKEAFKVHGIEAKGVTIDVPAMVARKANIVKNLTGGIA TLFKANGVTSFEGHGKLIANKOVEVTGLDGKTOVLEAENVI IASGSRPVEI IPP APLTDDIIVDSTGALEFQAVPKKLGVIGAGVIGLELGSVWARLGAEVTVLEAL DKFLPAADE OIAKEALKVLTKQGLNI RLGARVTASEVKKKQVTVTETDANGEQ KETFDKLIVAVGRRPVTTDLIAADSGVTLDERGFI YVDDHCKT SVPGVFAIGD VVRGAMLAHKASEEGVMVAER IAGHKAOMNYDL I PSVIYTHPE IAWVGKTEQT LKAEGVEVNVGT FPFAASGRAMAANDTTGLVKVIADAKTDRVLGVHVIGPSAA ELVQQGAIGMEFGTSAEDLGMMVFSHPTLSEALHEAALAVNGHAIHIANRKKR PA12

MKLKNTLGVVIGSLVAASAMNAFAQGQNSVEIEAFGKRYFTDSVRNMKNADLY GGSIGYFLTDDVELALSYGEYHDVRGTYETGNKKVHGNLTSLDAI YHFGTPGV GLRPYVSAGLAHQNITNINSDSQGRQQMTMANIGAGLKYYFTENFFAKASLDG QYGLEKRDNGHOGEWMAGLGVGFNFGGSKAAPAPEPVADVCSDSDNDGVCDNV DKCPDT PANVTVDANGCPAVAEVVRVQLDVKEDFDKSKVKENSYADIKNLADF MKQYPSTSTTVEGHTDSVGTDAYNQKLSERRANAVRDVLVNEYGVEGGRVNAV GYGESRPVADNATAEGRAINRRVEAEVEAEAK

PA14

MGKI IGIDLGTTNSCVAILENGNVKVIENAEGARTTPSIIAYTNDGETLVGQP AKRQAVTNPQNTLYAVKRLIGRRFEENVVQKDIQMVPYSIVKADNGDAWVEVK GQKMAPPOISAEVLKKMKKTAEDYLGEPVTEAVITVPAYFNDSQRQATKDAGR IAGLDVKRI INEPTAAALAYGLDKAKGDHTVIVYDLGGGTFDVSVIEIAEVDG EHQFEVLATNGDTFLGGEDFDIRLIDYLVDEFKKESGINLKGDPLAMORLKEA AEKAKIELSSTOOTDVNLPYVTADASGPKHLNVKVSRAKLESLVEDLVORTIE PCRTALKDAGLDVSDIHEVILVGGQTRMPLVQKTVAEFFGKEARKDVNPDEAV AVGAAIQGAVLAGDVKDVLLLDVTPLTLGIETLGGVMTGLIEKNTTIPTKKSO VFSTADDNOGAVTIHVLOGERKQAAQNKSLGKFDLADIPPAPRGVPQIEVTFD IDANGILHVSAKDKATGKQQS IVIKASSGLSEDEIQQMVRDAEANAEEDRKFE ELAAARNOGDALVHATRKMITEAGDKATAEDKATIEKALGELEAAVKGDDKAE IEAKMNALSOASTPLAOKMYAEQAOOGEDAPOGEOAKAADDVVDAEFEEVKDN $\mathrm{K}$

Fig. 7. Fourteen $P$. aeruginosa proteins identified are shown, with peptides sequenced by $\mu \mathrm{LC} / \mathrm{MS} / \mathrm{MS}$ underlined. Peptides containing a missed tryptic cleavage site are indicated with a bolded amino acid (K or $\mathbf{R})$. 
Table 1. Summary of proteins identified from 2-D gels of $P$. aeruginosa extracts

\begin{tabular}{|c|c|c|c|c|c|c|c|}
\hline $\begin{array}{l}\text { Spot } \\
\text { no. }\end{array}$ & Relationship* & $\begin{array}{l}\text { Mol. } \\
\text { mass } †\end{array}$ & $\mathrm{pI} \dagger$ & Identification and accession no. $\neq$ & Source $\mathbb{S}$ & $\begin{array}{l}\text { Mol. } \\
\text { mass } \|\end{array}$ & $\mathrm{pI} \|$ \\
\hline 1 & $383 c$ & 18 & $9 \cdot 0$ & $\begin{array}{l}\text { Outer-membrane protein H1 } \\
279973\end{array}$ & $\mathrm{~Pa}$ & $21 \cdot 6$ & $9 \cdot 00$ \\
\hline 2 & $383 c$ & 25 & $6 \cdot 0$ & $\begin{array}{l}\text { L25 ribosomal protein } \\
1173000\end{array}$ & $\mathrm{Hi}$ & $22 \cdot 0$ & $5 \cdot 81$ \\
\hline 3 & $383 \mathrm{u}$ & 20 & $4 \cdot 0$ & $\begin{array}{l}\text { Outer-membrane protein F } \\
\text { P13794 }\end{array}$ & $\mathrm{Pa}$ & $37 \cdot 6$ & $4 \cdot 98$ \\
\hline 4 & $383 \mathrm{u}$ & 20 & $4 \cdot 5$ & $\begin{array}{l}\text { Alkylhydrogenperoxide reductase } \\
965473\end{array}$ & Lp & $22 \cdot 1$ & $5 \cdot 88$ \\
\hline 5 & $383 \mathrm{u}$ & 20 & $5 \cdot 0$ & $\begin{array}{l}\text { Iron superoxide dismutase } \\
\text { AF121079 }\end{array}$ & Ps & $21 \cdot 4$ & $5 \cdot 44$ \\
\hline 6 & 3830 & 30 & $6 \cdot 0$ & $\begin{array}{l}\text { Chitin-binding protein } \\
\text { AF196565 }\end{array}$ & $\mathrm{Pa}$ & $41 \cdot 9$ & $6 \cdot 65$ \\
\hline 7 & 3830 & 40 & $6 \cdot 0$ & $\begin{array}{l}\text { Chitin-binding protein } \\
\text { AF196565 }\end{array}$ & $\mathrm{Pa}$ & $41 \cdot 9$ & $6 \cdot 65$ \\
\hline 8 & 3830 & 40 & $6 \cdot 3$ & $\begin{array}{l}\text { Ornithine transcarbamoylase } \\
\text { chain A } \\
1943014\end{array}$ & $\mathrm{~Pa}$ & $37 \cdot 9$ & $6 \cdot 25$ \\
\hline 9 & 3830 & 50 & $6 \cdot 4$ & $\begin{array}{l}\text { Catalase isozyme A } \\
\text { AF0 } 47025\end{array}$ & $\mathrm{~Pa}$ & $55 \cdot 6$ & $6 \cdot 21$ \\
\hline 10 & $383 o$ & 50 & $6 \cdot 8$ & $\begin{array}{l}\text { Dihydrolipoamide dehydrogenase } \\
\text { chain A } \\
494262\end{array}$ & $\mathrm{Pf}$ & $50 \cdot 0$ & $6 \cdot 47$ \\
\hline 11 & $2192 \mathrm{u}$ & 25 & $6 \cdot 0$ & $\begin{array}{l}\text { Alkylhydrogenperoxide reductase } \\
965473\end{array}$ & Lp & $22 \cdot 1$ & $5 \cdot 88$ \\
\hline 12 & 21920 & 40 & $5 \cdot 0$ & $\begin{array}{l}\text { Outer-membrane protein } \mathrm{F} \\
\text { P13794 }\end{array}$ & $\mathrm{Pa}$ & $37 \cdot 6$ & 4.98 \\
\hline 13 & $2192 \mathrm{u}$ & 60 & $5 \cdot 0$ & $\begin{array}{l}\text { S1 ribosomal protein } \\
42900\end{array}$ & Ec & $61 \cdot 0$ & $4 \cdot 86$ \\
\hline 14 & $2192 \mathrm{u}$ & 70 & $5 \cdot 0$ & $\begin{array}{l}\text { DnaK protein } \\
\text { AF135163 }\end{array}$ & Ps & $68 \cdot 9$ & 4.93 \\
\hline
\end{tabular}

* Spots cored from gels of proteins of P. aeruginosa nonmucoid 383 (Fig. 3a) and mucoid 2192 (Fig. 3b); c, common; u, unique; o, overexpressed. The identity of all overexpressed and common proteins was determined to be identical between gels, except for PA2 and PA12, which, for technical reasons, were not recovered.

† Molecular mass $(\mathrm{kDa})$ and $\mathrm{pI}$ calculated from gel.

$\ddagger$ Identification of amino acid sequence derived from the Pseudomonas Genome Project 15 December 1999). ORFs found were subsequently searched using BLAST (National Center for Biotechnology Information) against their non-redundant database. Accession numbers are from NCBI, SWISS-PROT or Genpept.

SSource of derived identification: $\mathrm{Pa}$, Pseudomonas aeruginosa; Hi, Haemophilus influenzae; Lp, Legionella pneumophila; Ps, Pseudomonas syringae; Pf, Pseudomonas fluorescens; Ec, Escherichia coli.

$\|$ Molecular mass $(\mathrm{kDa})$ and $\mathrm{pI}$ calculated from P. aeruginosa ORFs derived from the Pseudomonas Genome Project (15 December 1999).

each gel as determined by image analysis software using the other identified spots as references.

\section{Outer-membrane proteins}

OprH. The protein gel spot 1 was common between strains 383 and 2192 and was detected on the 2-D gels at a position corresponding to molecular mass $18 \mathrm{kDa}$ and pI 9.0. Amino acid sequences obtained from this spot (PA1) identified this protein as the outer-membrane protein OprH, previously detected in both mucoid and nonmucoid strains (Kelly et al., 1990). OprH is suggested to be responsible for resistance to polycations, polymyxin B, gentamicin and EDTA (Bell et al., 1991).

OprF. The protein gel spots 3 and 12 were observed to be unique for strain 383 and overexpressed in strain 2192, respectively. Gel spot 3 ran at a molecular mass of approximately $20 \mathrm{kDa}$ and a $\mathrm{pI}$ of $4 \cdot 0$. Spot 12 ran at a molecular mass of approximately $40 \mathrm{kDa}$ and a pI of $5 \cdot 0$. 
Surprisingly, the amino acid sequences derived from both of these spots corresponded to a single protein, OprF. The molecular mass and pI observed on the 2-D gel of the 2192 protein are similar to those derived from the amino acid sequence, but the migration of the gel spot 3 showed a significantly smaller molecular mass with a lower pI (Table 1).

OprF is a multifunctional non-specific porin located in the outer membrane of $P$. aeruginosa that plays a role in maintenance of cell shape and is required for growth in a low-osmolarity environment (Rawling et al., 1998). This protein has been shown to be expressed in both mucoid and nonmucoid strains, but at the same molecular mass (Kelly et al., 1990). This suggested that the smaller size of OprF in 383 might represent a specific breakdown product. Supporting the idea that degradation had occurred, the amino acid sequences identified in protein gel spot 3 (PA3) corresponded only to the Cterminal portion of OprF (Fig. 7).

To determine if OprF was degraded during the processing before 2-D gel electrophoresis, we compared whole cells to French-pressed cells and followed OprF expression after one-dimensional SDS-PAGE and Western immunoblotting. For this analysis, we used mAb MA71 (kindly provided by Dr Robert E. W. Hancock, University of British Columbia, Vancouver, Canada), which is specific for the N-terminal region of OprF (Martin et al., 1993). Western immunoblotting using MA7-1 showed that there was degradation of OprF in strain 383 during the cell lysis; the size of the degradation product was about $25 \mathrm{kDa}$. This product is larger than spot 3 observed on the 2-D gels, and reacted with the $\mathrm{N}$ terminal specific $\mathrm{mAb}$; this suggests that the $\mathrm{OprF}$ is specifically degraded during processing, releasing an approximately $25 \mathrm{kDa} \mathrm{N}$-terminal fragment and an approximately $20 \mathrm{kDa}$ C-terminal fragment. Interestingly, these sizes are similar to the functional demarcation of the N-terminal domain of OprF, which is unique to $P$. aeruginosa and is important for stable expression, and the C-terminal domain, which is more conserved among Gram-negative outer-membrane proteins and is important for peptidoglycan association (Rawling et al., 1998). The degradation of OprF was not specific to 383 but seemed to occur more readily in this strain; this may be due to increased activities of some $P$. aeruginosa proteases in nonmucoid strains compared to mucoid strains (Ohman \& Chakrabarty, 1982). After subsequent processing steps, both 2192 and 383 showed degradation of OprF (data not shown).

\section{Proteins involved in resistance to oxidative damage}

SOD. The protein gel spot $5(20 \mathrm{kDa}, \mathrm{pI} 5)$ was found to be unique to strain 383 . Based on the amino acid sequences derived from this spot, PA5 was found to correspond to the iron superoxide dismutase (Fe-SOD). This protein is encoded by the $\operatorname{sodB}$ gene and is one of the two SOD proteins detected in $P$. aeruginosa. The FeSOD is thought to be more important than the second SOD (the manganese SOD, Mn-SOD) for aerobic growth, resistance to paraquat and maximal pyocyanin synthesis (Hassett et al., 1995). Contrary to our results, other workers have noted that Mn-SOD activity was increased in a mucoid strain compared to a nonmucoid strain, while the level of Fe-SOD did not show any apparent difference in activity (Hassett et al., 1993).

Catalase. The protein gel spot 9, which migrated at approximately $50 \mathrm{kDa}$ and $\mathrm{pI} 6.4$ on the $2-\mathrm{D}$ gel, was overexpressed in the nonmucoid strain 383 compared to the mucoid strain 2192. Upon examination of the amino acid sequences derived from this spot, PA9 was found to correspond to the catalase isozyme A. This protein, encoded by the kat $A$ gene, is the major of two catalases in $P$. aeruginosa. KatA is important for resistance to $\mathrm{H}_{2} \mathrm{O}_{2}$ (Elkins et al., 1999). Consistent with our finding by 2-D gel electrophoresis, catalase activity has been observed to be greater in nonmucoid strains compared to mucoid strains (Brown et al., 1995).

Alkylhydrogenperoxide reductase. The protein gel spots 4 (20 kDa, pI 4.5) and 11 (25 kDa, pI 6.0) were identified as unique to 383 and 2192, respectively. Upon MS analysis, the amino acid sequences from each of these spots were found to correspond to a $P$. aeruginosa paralogue of an alkylhydrogenperoxide reductase from Legionella pneumoniae. This enzyme catalyses the reduction of alkylhydrogenperoxide to the corresponding alcohol. Using a similar proteomic analysis, another alkylhydrogenperoxide reductase, $\mathrm{AhpC}$, was found to be induced under sulfate limitation conditions in strain PAO1 (Quadroni et al., 1999).

\section{Housekeeping proteins and enzymes}

$50 \mathrm{~S}$ ribosomal protein $\mathrm{L} 25$. The protein gel spot 2 migrated on the 2-D gel at $25 \mathrm{kDa}$ and $\mathrm{pI} 6.0$ and was observed to be common between strains 383 and 2192. Based on the amino acid sequence of this spot, the $P$. aeruginosa ORF encodes a protein of molecular mass $22 \cdot 0 \mathrm{kDa}$ and $\mathrm{pI}$ 5.81 with homology to the L25 protein of the large subunit of the ribosome.

30 S ribosomal protein S1. Protein gel spot $13(60 \mathrm{kDa}$, pI $5 \cdot 0$ ) was unique to strain 2192. The amino acid sequence of this protein spot (PA13) corresponded to the S1 ribosomal protein of the small subunit of the ribosome. Based on the amino acid sequence, the inferred $P$. aeruginosa S1 protein has a molecular mass of 61.0 and a $\mathrm{pI}$ of $4 \cdot 86$.

DnaK. Protein gel spot $14(70 \mathrm{kDa}, \mathrm{pI} 5 \cdot 0)$ was found to be unique for strain 2192. The amino acid sequences corresponded to the protein identified as DnaK. This protein is a chaperone that is also known as Hsp70. The molecular mass of this protein based on the amino acid sequence is $68.9 \mathrm{kDa}$ and the $\mathrm{pI}$ is 4.93 .

Ornithine carbamoyltransferase. The protein gel spot 8 (40 kDa, pI 6.3) was overexpressed on the 2-D gel of strain 383. The amino acid sequence derived from this spot (PA8) was determined to be ornithine transcarba- 
moylase chain A. This protein catalyses the reaction between ornithine and carbamoyl phosphate to produce citrulline and orthophosphate.

Dihydrolipoamide dehydrogenase chain $\mathbf{A}$. The protein gel spot $10(50 \mathrm{kDa}, \mathrm{pI} 6 \cdot 8)$ was overexpressed on the 2-D gel of strain 383. The amino acid sequence derived from this spot, PA10, corresponded to the paralogue of the Lpd protein, dihydrolipoamide dehydrogenase chain A (lipoamide dehydrogenase). This protein is a flavoprotein component of multi-enzyme complexes catalysing the oxidative decarboxylation of $\alpha$-ketoacids in the Krebs cycle.

Chitin-binding protein. The protein gel spots $6(30 \mathrm{kDa}$, pI 6.0) and $7(40 \mathrm{kDa}, \mathrm{pI} 6.0)$ were both overexpressed in strain 383 and were found to correspond to the chitinbinding protein ChpD. The amino acid sequences derived from spot 7 (PA7) correspond to regions covering the entire chitin-binding protein, while protein gel spot 6 (PA6) did not include amino acid sequences corresponding to the extreme $\mathrm{N}$-terminal or $\mathrm{C}$-terminal region of this protein (Fig. 7). This result suggests that the smaller size of protein gel spot 6 (PA6) may represent the major recognized $30 \mathrm{kDa}$ degradation product of the chitin-binding protein (Folders et al., 2000). Interestingly, ChpD is a secreted protein, but in our analysis both the full-length and the degradation product were detected as cell-associated.

\section{DISCUSSION}

With modifications to cell lysis, incorporation of a phenol extraction step and DNase I and RNase treatment, the $P$. aeruginosa protein isolation protocol has been standardized to produce reproducible and useful results using 2-D gel electrophoresis and visualization by Coomassie staining of the gels of lung isolates. A spot visualized by Coomassie staining represents at least $1 \mathrm{pmol}$ of protein and is sufficient for subsequent MS analysis. Product-ion spectra can be automatically searched against the Pseudomonas Genome Project database or other databases to yield highly accurate identification of proteins. Data generation from the product-ion spectrum is highly interpretable, containing sufficient information to deduce the entire peptide sequence.

Three key advantages of protein identification by MS are the sensitivity of the analysis, the amount of information generated and the speed of the analysis and identification. The sensitivity of the system used gives limits of detection approaching $0.5 \mathrm{fmol}$ of a peptide on the micro-capillary column in routine operation. With this sensitivity, any protein spot that can be detected with Coomassie blue staining (and some with silver staining) contains adequate amounts of protein for identification. Further, the analysis is sufficiently automated that peptides are detected and product-ion spectra recorded in a single analysis, resulting in approximately $500 \mathrm{MS} / \mathrm{MS}$ spectra recorded per analysis. Not all
MS/MS spectra are due to peptides, and not all peptides are detected, but the peptides that are detected typically cover $30-80 \%$ of the protein sequence. Finally, the time required to perform the analysis and identification is less than 45 min per sample.

The desired end result of our research is to develop a complete map of the proteins expressed in $P$. aeruginosa and, more importantly, to identify protein differences between isolates from initial infections and chronic infections in CF. The entire genome sequence of $P$. aeruginosa PAO1 is now complete; thus amino acid sequence data, or mass alone, will allow the identification of the relevant proteins, which in turn will lead to the genes responsible for them. We hope further experimentation will uncover information about the nature of the genetic mutations or regulatory alterations in these proteins that facilitate their change in expression and define their importance to the infection process. The first 14 spots selected for this analysis have been identified; however further characterization is required before the full significance of these differences in expression is completely understood.

We recognize that there are a number of limitations to this proteomic approach. The most obvious problem is that not all $P$. aeruginosa strains are equivalent to strain PAO1. In fact even some strains of PAO1 have been shown to have differences with respect to antibiotic resistance and virulence (Preston et al., 1995; M. Preston $\&$ G. B. Pier, personal communication). In one case where strains from CF patients have been compared to PAO1, a major clone $\mathrm{C}$ had a genome that was observed to be almost $600 \mathrm{~kb}$ larger than that of PAO1 (Schmidt et al., 1996). The sequence of this additional DNA from clone $\mathrm{C}$ is not known, but it may include genes needed for survival in the CF lung environment. The analysis of genes and their products that are unique to CF isolates may aid in the identification and isolation of useful drug targets. Interestingly, in our limited analysis of proteins by 2-D gel electrophoresis and MS, no proteins were uncovered that did not have corresponding genes in the PAO1 sequence database.

In our 2-D gel analysis we assessed only the cellassociated proteins from the $P$. aeruginosa strains. $P$. aeruginosa secretes and releases a large number of factors, including toxins, enzymes, pyocins, siderophores and polysaccharides, that are known to have a role in virulence (Pollack, 2000). The expression of many of these factors is known to be different in initial versus chronic isolates of $P$. aeruginosa. Thus many of the factors known to vary in expression during different infections were not investigated in this survey.

In the studies presented here we used two strains of $P$. aeruginosa that were isolated from the same patient $2 \mathrm{~d}$ apart. It was important to first confirm that these strains were indeed isogenic so that differences in protein expression could be attributed to the differences between related but phenotypically distinct strains, rather than due to non-specific strain differences. We used three genotypic methods, REA, RAPD and PFGE, to confirm 
the relatedness of these strains. Genotyping was more appropriate for this analysis because other typing methods for $P$. aeruginosa are less discriminatory for comparing $\mathrm{CF}$ isolates due to the phenotypic changes associated with the chronic form. The chronic form can be altered in characteristics normally used for comparisons, such as bacteriophage susceptibility, bacteriocin production, motility and mucoidy (Speert et al., 1994). Similarly, serotyping, which depends on the reaction of the immunodominant LPS O antigen with specific antiserum, is usually not useful for typing CF isolates. The loss of $\mathrm{O}$ antigen, resulting in a strain that is non-typable (not reacting with any antiserum) or polytypable (reacting with multiple sera), is one of the hallmarks of the conversion in chronically infecting CF strains (Hancock et al., 1983). In fact, strain 383 was serotyped as serogroup O1 and 2192 was non-typable (G. B. Pier, personal communication).

The results of comparison of these strains by onedimensional analysis of outer-membrane proteins were similar to those reported in previous investigations. Goldberg \& Ohman (1987) noted an approximately $58 \mathrm{kDa}$ protein present in the membrane fraction of a mucoid CF strain that was missing from both a constructed nonmucoid derivative and a spontaneous nonmucoid strain. Kelly et al. (1990) observed that mucoid strains from CF patients displayed prominent proteins at $55 \mathrm{kDa}$ and $25 \mathrm{kDa}$. They also noted the overproduction of a $44 \mathrm{kDa}$ protein in laboratoryderived nonmucoid revertants of CF isolates. Grabert et al. (1990) identified a $54 \mathrm{kDa}$ outer-membrane protein specific for mucoid strains. The N-terminal amino acid sequence corresponded to the inferred amino acid sequence of the alginate gene product $\mathrm{AlgE}$, which is suggested to be involved in export of alginate (Chu et al., 1991; Rehm et al., 1994). More recently, Mathee et al. (1999) isolated outer-membrane proteins of a mucoid variant of the laboratory strain PAO1, noted a $54 \mathrm{kDa}$ protein, and identified it as AlgE. These workers also detected other proteins whose expression was up- or down-regulated in these different strains; however, the molecular masses of these proteins were not presented. The variability in the expression of the outer-membrane proteins between initial and chronic infections is important to acknowledge, as these proteins may be considered likely candidates for vaccine development.

Two of the proteins investigated in this small sample of 14 proteins showed expression in the nonmucoid strain versus the mucoid strain that was as anticipated. OprH had been shown to be expressed in both mucoid and nonmucoid strains at about the same level (Kelly et al., 1990). KatA, which encodes the major catalase, was overexpressed in the nonmucoid strain 383 compared to the mucoid strain 2192; catalase activity has been previously reported to be greater in nonmucoid strains (Brown et al., 1995).

Three protein pairs were identified as the same protein but migrating at different sizes in each strain or within the same strain. For two of these pairs, the differences in sizes could be attributed to degradation of the protein.
Analysis of one protein pair, corresponding to $P$. aeruginosa OprF, suggests that the source of the size variation between 383 and 2192 is the result of more rapid degradation of OprF in 383 during the extraction process. Based on the location of the peptides making up the $383 \mathrm{OprF}$, we could conclude that this degradation product included the C-terminal region of this protein. Similarly, the smaller molecular mass of one of the spots from 383 (PA6), corresponding to the chitin-binding protein $\mathrm{ChpD}$, is likely due to degradation, resulting in a truncated protein. The degradation of $\mathrm{ChpD}$ has been previously shown to be due to the action of elastase (Folders et al., 2000). In both cases, the location of the peptides in the amino acid sequence helped confirm composition of the degradation products that were observed on the 2-D gels. These findings have aided in the appreciation that differences in protein expression may be due to differential degradation as well as differential expression.

For this initial study, 2-D gels were produced that covered a broad pI range (3-10). Gels were also produced separating proteins from strains 383 and 2192 over the pI ranges 4-7 and 6-11 (data not shown). Unlike the 3-10 gradients, these narrower $\mathrm{pI}$ gradients are linear, provide a higher resolution for isoelectric focusing, and allow loading of greater amount of protein; typically twice as much protein can be loaded in the narrow pI range strips. The increased loading associated with this technique, combined with sufficient resolution in these 2-D gel systems, allows detection and identification of low-copy proteins in these complex mixtures. These expanded $\mathrm{pI}$ ranges are generally used for sections of the gel where the broad $\mathrm{pI}$ range provides inadequate resolution of specific proteins. However, in an initial study such as this, the broad pI range provides a more accurate picture of all the proteins being expressed.

Peptide sequence information, obtained by de novo interpretation of the product-ion spectra, can be used to design oligonucleotide probes suitable for cloning novel proteins where no database matches can be found (Mandal et al., 1999, Mehta et al., 2000). Additional information can be derived from this proteomic approach when it is used in conjunction with Western blot analysis. An example of this sort of investigation has been undertaken in Helicobacter pylori (McAtee et al., 1998), whose genome sequence was completed in 1997 (Tomb et al., 1997). McAtee et al. (1998) used pooled sera from $H$. pylori-infected patients to detect proteins recognized by the immune system. The goals of this type of proteomic approach, together with immunological detection, are to improve serological tests, to identify potential targets for antimicrobial therapy, and to develop vaccines.

In the case of $P$. aeruginos $a$, other proteomic studies that will be informative include the use of specific mutants of PAO1. For example, proteomic comparisons of a regulatory mutant to wild-type PAO1 will allow the determination of the differences in protein expression between the two strains. Similarly, comparison of PAO1 
proteins expressed under varying growth conditions can indicate which gene products are required in these specific conditions (Quadroni et al., 1999).

In summary, we have detected differences between proteins expressed by $\mathrm{CF}$ isolates of $P$. aeruginosa that have phenotypes associated with the initial versus chronic infection process; for this analysis strains were grown under standard laboratory conditions. We were able to obtain high-quality, reproducible displays of the patterns of protein expressed in these isolates by 2-D gel electrophoresis as a basis to detect differences in expression and to provide sufficient amounts of individual proteins for subsequent sequencing and identification by MS/MS. While the growth conditions used for these studies likely do not completely mimic in vivo conditions, they represent a reasonable starting point for this type of investigation. The long-term goal of this study is to identify $P$. aeruginosa proteins that are uniquely expressed during the chronic infection process, to use as potential protein targets for novel drug design or as vaccine candidates.

\section{ACKNOWLEDGEMENTS}

We are grateful to Dr Eshwar Mahenthiralingam (Cardiff University) for performing the PFGE analysis. We thank Amy Staab, Yan Ren and Betty Shiberu for excellent technical assistance and Cathryn Varga for excellent graphic assistance. We also thank Drs Amy H. Bouton, Charles R. Dean, Clifton V. Franklund and Jay W. Fox for helpful discussions. This research was supported by NIH grants (R01 AI35674 and R01 AI37632) to J.B.G. and a Cystic Fibrosis Foundation Student Traineeship (HANNA99H0) to S.L.H.

\section{REFERENCES}

Bell, A., Bains, M. \& Hancock, R. E. (1991). Pseudomonas aeruginosa outer membrane protein $\mathrm{OprH}$ : expression from the cloned gene and function in EDTA and gentamicin resistance. $J$ Bacteriol 173, 6657-6664.

Bini, L., Sanchez-Campillo, M., Santucci, A. \& 9 other authors (1996). Mapping of Chlamydia trachomatis proteins by immobiline-polyacrylamide two-dimensionalelectrophoresis : spotidentification by $\mathrm{N}$-terminal sequencing and immunoblotting. Electrophoresis 17, 185-190.

Brown, S. M., Howell, M. L., Vasil, M. L., Anderson, A. J. \& Hassett, D. J. (1995). Cloning and characterization of the katB gene of Pseudomonas aeruginosa encoding a hydrogen peroxideinducible catalase: purification of KatB, cellular localization, and demonstration that it is essential for optimal resistance to hydrogen peroxide. J Bacteriol 177, 6536-6544.

Chu, L., May, T. B., Chakrabarty, A. M. \& Misra, T. K. (1991). Nucleotide sequence and expression of the algE gene involved in alginate biosynthesis by Pseudomonas aeruginosa. Gene 107, $1-10$.

Cordwell, S. J., Nouwens, A. S., Verrills, N. M., McPherson, J. C., Hains, P. G., Van Dyk, D. D. \& Walsh, B. D. (1999). The microbial proteome database - an automated laboratory catalogue for monitoring protein expression in bacteria. Electrophoresis 20, 3580-3588.

Dean, C. R., Franklund, C. V., Retief, J. D., Coyne, J. M. J., Hatano, K., Evans, D. J., Pier, G. B. \& Goldberg, J. B. (1999). Charac- terization of the serogroup O11 O-antigen locus of Pseudomonas aeruginosa PA103. J Bacteriol 181, 4275-4284.

Elkins, J. G., Hassett, D. J., Stewart, P. S., Schweizer, H. P. \& McDermott, T. R. (1999). Protective role of catalase in Pseudomonas aeruginosa biofilm resistance to hydrogen peroxide. Appl Environ Microbiol 65, 4594-4600.

Ernst, R. K., Yi, E. C., Guo, L., Lim, K. B., Burns, J. L., Hackett, M. \& Miller, S. I. (1999). Specific lipopolysaccharide found in cystic fibrosis airway Pseudomonas aeruginosa. Science 286, 1561-1565.

Folders, J., Tommassen, J., Van Loon, L. C. \& Bitter, W. (2000). Identification of a chitin-binding protein secreted by Pseudomonas aeruginosa. J Bacteriol 182, 1257-1263.

Goldberg, J. B. \& Ohman, D. E. (1987). Construction and characterization of Pseudomonas aeruginosa algB mutants: role of $\operatorname{alg} B$ in high-level production of alginate. J Bacteriol 169, 1593-1602.

Govan, J. R. W. \& Deretic, V. (1996). Microbial pathogenesis in cystic fibrosis: mucoid Pseudomonas aeruginosa and Burkholderia cepacia. Microbiol Rev 60, 539-574.

Grabert, E., Wingender, J. \& Winkler, U. K. (1990). An outer membrane protein characteristic of mucoid strains of Pseudomonas aeruginosa. FEMS Microbiol Lett 68, 83-88.

Hancock, R. E. W. \& Nikaido, H. (1978). Outer membranes of Gram-negative bacteria. XIX. Isolation from Pseudomonas aeruginosa PAO1 and use in reconstitution and definition of the permeability barrier. J Bacteriol 136, 381-390.

Hancock, R. E. W., Mutharia, L. M., Chan, L., Darveau, R. P., Speert, D. P. \& Pier, G. B. (1983). Pseudomonas aeruginosa isolates from patients with cystic fibrosis: a class of serum-sensitive, nontypable strains deficient in lipopolysaccharide $\mathrm{O}$ side chains. Infect Immun 42, 170-177.

Hancock, R., Siehnel, R. \& Martin, N. (1990). Outer membrane proteins of Pseudomonas. Mol Microbiol 4, 1069-1075.

Hassett, D. J., Woodruff, W. A., Wozniak, D. J., Vasil, M. L., Cohen, M. S. \& Ohman, D. E. (1993). Cloning and characterization of the Pseudomonas aeruginosa sodA and $\operatorname{sodB}$ genes encoding manganese- and iron-cofactored superoxide dismutase: demonstration of increased manganese superoxide dismutase activity in alginate-producing bacteria. J Bacteriol 175, 7658-7665.

Hassett, D. J., Schweizer, H. P. \& Ohman, D. E. (1995). Pseudomonas aeruginosa $\operatorname{sod} A$ and $\operatorname{sod} B$ mutants defective in manganese- and iron-cofactored superoxide dismutase activity demonstrate the importance of the iron-cofactored form in aerobic metabolism. J Bacteriol 177, 6330-6337.

Holloway, B. W., Römling, U. \& Tümmler, B. (1994). Genomic mapping of Pseudomonas aeruginosa PAO. Microbiology 140, 2907-2929.

Kelly, N. M., MacDonald, M. H., Martin, N., Nicas, T. \& Hancock, R. E. W. (1990). Comparion of the outer membrane protein and lipopolysaccharide profiles of mucoid and nonmucoid Pseudomonas aeruginosa. J Clin Microbiol 28, 2017-2021.

Kersulyte, D., Struelens, M. J., Deplano, A. \& Berg, D. E. (1995). Comparison of arbitrarily primed PCR and macrorestriction (pulsed-field gel electrophoresis) typing of Pseudomonas aeruginosa strains from cystic fibrosis patients. J Clin Microbiol 33, 2216-2219.

Kropinski, A. M., Chan, L. C. \& Milazzo, F. H. (1979). The extraction and analysis of lipopolysaccharides from Pseudomonas aeruginosa strain $\mathrm{PAO}$, and three rough mutants. Can J Microbiol 25, 390-398.

McAtee, C. P., Lim, M. Y., Fung, K., Velligan, M., Fry, K., Chow, T. \& Berg, D. E. (1998). Identification of potential diagnostic and vaccine candidates of Helicobacter pylori by two-dimensional gel 
electrophoresis, sequence analysis, and serum profiling. Clin Diagn Lab Immunol 5, 537-542.

Mahenthiralingam, E., Campbell, M. E., Foster, J., Lam, J. S. \& Speert, D. P. (1996). Random amplified polymorphic DNA typing of Pseudomonas aeruginosa isolates recovered from patients with cystic fibrosis. J Clin Microbiol 34, 1129-1135.

Maher, W. E., Kobe, M. \& Fass, R. J. (1993). Restriction endonuclease analysis of clinical Pseudomonas aeruginosa strains: useful epidemiologic data from a simple and rapid method. J Clin Microbiol 31, 1426-1429.

Mandal, A., Naaby-Hansen, S., Wolkowicz, M. J. \& 9 other authors (1999). FSP95, a testis-specific 95-kilodalton fibrous sheath antigen that undergoes tyrosine phosphorylation in capacitated human spermatozoa. Biol Reprod 61, 1184-1197.

Martin, N. L., Rawling, E. G., Wong, R. S. Y., Rosok, M. \& Hancock, R. E. W. (1993). Conservation of surface epitopes in Pseudomonas aeruginosa outer membrane porin protein OprF. FEMS Microbiol Lett 113, 261-266.

Mathee, K., Ciofu, O., Sternberg, C. \& 9 other authors (1999). Mucoid conversion of Pseudomonas aeruginosa by hydrogen peroxide: a mechanism for virulence activation in the cystic fibrosis lung. Microbiology 145, 1349-1357.

Mehta, A., Kinter, M. T., Sherman, N. E. \& Driscoll, D. M. (2000). Molecular cloning of apobec-1 complementation factor, a novel RNA-binding protein involved in the editing of apolipoprotein B mRNA. Mol Cell Biol 20, 1846-1854.

Ohman, D. E. \& Chakrabarty, A. M. (1982). Utilization of human respiratory secretions by mucoid Pseudomonas aeruginosa of cystic fibrosis origin. Infect Immun 37, 662-669.

Pier, G. B. (1998). Pseudomonas aeruginosa: a key problem in cystic fibrosis. Am Soc Microbiol News 64, 339-347.

Pollack, M. (2000). Pseudomonas aeruginosa. In Principles and Practice of Infectious Diseases, pp. 2310-2335. Edited by G. L. Mandell, J. E. Bennett \& R. Dolin. Philadelphia: Churchill Livingstone.

Preston, M. J., Fleiszig, S. M. J., Zaidi, T. S., Goldberg, J. B., Shortridge, V. D., Vasil, M. L. \& Pier, G. B. (1995). Rapid and sensitive method for evaluating Pseudomonas aeruginosa virulence factors during corneal infections in mice. Infect Immun 63, 3497-3501.
Quadroni, M., James, P., Dainese-Hatt, P. \& Kertesz, M. A. (1999). Proteome mapping, mass spectrometric sequencing and reverse transcription-PCR for characterization of the sulfate starvationinduced response in Pseudomonas aeruginosa PAO1. Eur J Biochem 266, 986-996.

Rawling, E. G., Brinkman, F. S. L. \& Hancock, R. E. W. (1998). Roles of the carboxy-terminal half of Pseudomonas aeruginosa major outer membrane protein OprF in cell shape, growth in lowosmolarity medium, and peptidoglycan association. J Bacteriol 180, 3556-3562.

Rehm, B. H. A., Grabert, E., Hein, J. \& Winkler, U. K. (1994). Antibody response of rabbits and cystic fibosis patients to an alginate-specific outer membrane protein of a mucoid strain of Pseudomonas aeruginosa. Microb Pathog 16, 43-51.

Römling, U., Grothues, D., Koopman, U., Jahnke, B., Greipel, J. \& Tümmler, B. (1992). Pulsed-field gel electrophoresis analysis of a Pseudomonas aeruginosa pathovar. Electrophoresis 13, 646-648.

Schmidt, K. D., Tümmler, B. \& Römling, U. (1996). Comparative genome mapping of Pseudomonas aeruginosa $\mathrm{PAO}$ with $P$. aeruginosa $\mathrm{C}$, which belongs to a major clone in cystic fibrosis patients and aquatic habitats. J Bacteriol 178, 85-93.

Speert, D., Campbell, M., Puterman, M. L. \& 11 other authors (1994). A multicenter comparison of methods for typing strains of Pseudomonas aeruginosa predominantly from patients with cystic fibrosis. J Infect Dis 169, 134-142.

Sprott, G. C., Koval, S. F. \& Schnaitman, C. A. (1994). Cell fractionation. In Methods for General and Molecular Bacteriology, pp. 73-103. Edited by P. Gerhardt, R. G. E. Murray, W. A. Wood \& N. R. Krieg. Washington, DC: American Society for Microbiology.

Tomb, J., White, O., Kerlavage, A. R. \& 39 other authors (1997). The complete genome sequence of the gastric pathogen Helicobacter pylori. Nature 388, 539-548.

Vandamme, P., Mahenthiralingam, E., Holmes, B., Coenye, T., Hoste, B., De Vos, P., Henry, D. \& Speert, D. P. (2000). Identification and population structure of Burkholderia stabilis sp. nov. (formerly Burkholderia cepacia genomovar IV). J Clin Microbiol 38, 1042-1047.

Received 4 April 2000; revised 28 July 2000; accepted 2 August 2000. 